\title{
Analisis Video Views to Followers Ratio Instagram pada 5 Merk Kosmetik Lokal Terbaik
}

\author{
Luh Sri Widari \\ Sriwidari2211@gmail.com
}

\begin{abstract}
Instagram is a social media that is used as a place to spread and share news, interact with people, and get to know each other more closely.Instagram is a photo sharing software that allows users to take photos, apply digital filters, and share them to various social networking services. . The widespread use of Instagram makes researchers want to do a qualitative evaluation of the accounts contained on Instagram social media. This research was conducted on Instagram Accounts of Local Cosmetic Brands in Indonesia. This study uses quantitative exploratory methods to determine the credibility of the Instagram account performance of the Best Local Cosmetic Brands. The results of this study indicate that Emina Cosmetics is ranked first and has the best account performance credibility.
\end{abstract}

\begin{abstract}
ABSTRAK
Instagram adalah media sosial yang dipergunakan menjadi tempat menyebarkan dan berbagai berita, berinteraksi dengan orang banyak, dan dapat mengenal lebih dekat menggunakan sesama pengguna .Instagram adalah perangkat lunak berbagi foto yang memungkinkan pengguna mengambil foto, menerapkan filter digital, serta membagikannya ke berbagai layanan jejaring sosial . Maraknya penggunaan Instagram membuat para peneliti ingin melakukan evaluasi secara kualitatif terhadap akun - akun yang terdapat pada media sosial Instagram. Penelitian ini dilakukan pada Akun Instagram Merk Kosmetik Lokal di Indonesia. Penelitian ini menggunakan metode eksploratif kuantitatif untuk mengetahui kredibilitas dari performa akun Instagram Merk Kosmetik Lokal Terbaik. Hasil dari penelitian ini menunjukkan bahwa Emina Cosmetics meraih peringkat pertama dan memiliki kredibilitas performa akun terbaik.
\end{abstract}

Keyword : Social Media Instagram ; Merk Kosmetik Lokal Terbaik ; Video Views to Followers Ratio ; Analysis Media Social ; Instagram Marketing. 


\section{PENDAHULUAN}

Media Sosial adalah konten online yang dibuat menggunakan teknologi penerbitan yang sangat mudah diakses dan terukur (Prihatiningsih, 2017). Media sosial adalah sebuah media online, dengan para penggunanya bisa dengan mudah berpartisipasi, berbagi, dan menciptakan isi meliputi blog, jejaring sosial, wiki, forum dan dunia virtual. Blog, jejaring sosial dan wiki merupakan bentuk media sosial yang paling umum digunakan oleh masyarakat di seluruh dunia (Hager \& Wellein, 2021). Beberapa model media sosial yang banyak digunakan ialah YouTube, Facebook, Blog, Tweeter, Instagram serta lain-lain.

Salah satu media umum yg menjadi sorotan saat ini adalah Instagram. Diantara kelebihan Instagram, yang membuat banyak orang lebih tertarik mempromosikan produk mereka melalui media sosial Instagram. Instagram mempunyai jumlah pengguna yang tinggi serta menyebar di semua dunia. Selain itu, Instagram artinya media sosial yang dikhususkan untuk memposting gambar, sehingga tampilan primer yang ditangkap oleh para konsumen adalah berupa gambar visual.

Strategi pemasaran merupakan suatu wujud rencana sebuah perusahaan dalam bidang pemasaran untuk memperoleh hasil yang optimal. Ruang lingkup strategi pemasaran cukup luas di antaranya adalah strategi menghadapi persaingan, strategi produk, strategi harga, strategi tempat, dan trategi promosi (Haryanti et al., 2017). Berdasarkan pengertian di atas, maka dapat disimpulkan bahwa strategi pemasaran merupakan rangkaian suatu kegiatan yang terarah untuk mencapai sasaran dan dengan pola berpikir yang inovatif dan kreatif, untuk menghadapi kecenderungan yang terjadi di dalam perusahaan maupun di luar perusahaan, yang akan berpengaruh terhadap kepentingan maupun masa depan perusahaan sendiri.

Instagram adalah media sosial yang dipergunakan menjadi tempat menyebarkan dan berbagai berita, berinteraksi dengan orang banyak, dan dapat mengenal lebih dekat menggunakan sesama pengguna .Instagram adalah perangkat lunak berbagi foto yang memungkinkan pengguna mengambil foto, menerapkan filter digital, serta membagikannya ke berbagai layanan jejaring sosial . Maraknya penggunaan Instagram membuat para peneliti ingin melakukan evaluasi secara kualitatif terhadap akun - akun yang terdapat pada media sosial Instagram.

Beberapa para peneliti sudah melakukan penelitian yang terkait dengan penggunaan media sosial Instagram. contohnya seperti penelitian Instagram menjadi media online shop dan juga menjadi media memamerkan gaya hidup atau aktivitas sehari-hari dari pemilik akun. Dalam hal ini peranan sistem berita pada Instagram adalah sebagai prediksi, pendukung keputusan, serta keamanan . tetapi diantara beberapa penelitian yang telah ada mengenai Instagram, belum terdapat peneliti yang meneliti tentang pencarian rasio - rasio yang dapat digunakan sebagai indera ukur dalam menilai banyak sekali aspek di Instagram. 


\section{TINJAUAN PUSTAKA}

Dalam era modern saat ini, teknologi komunikasi sangat berdampak kuat bagi perkembangan media. Dengan itu, kita merasa sangat di mudahkan dalam memenuhi kebutuhan yang kita inginkan. Misalnya dengan menggunakan media internet. Melalui media internet, kita dapat memenuhi kebutuhan kita akan banyak hal seperti ilmu pengetahuan, mencari berita, bersosialisasi, berkerja, berbelanja, dan mempromosikan dengan mengiklankan sebuah produk.Komunikasi sangat penting bagi perusahaan atau penjual untuk melakukan sebuah promosi pemasaran. Sehingga apa yang akan dihasilkan oleh perusahaan dapat sampai langsung dengan jelas kepada konsumen. Pemasaran sangat berpengaruh besar pada perusahaan untuk melakukan sebuah promosi.

Bagi para penjual online kini dapat dengan mudah mempromosikan dengan cara mengiklankan produk yang ia tawarkan melalui media sosial. Promosi adalah salah satu usaha yang dilaksanakan oleh suatu perusahaan, yang merupakan elemen pemasaran yang sangat penting untuk meningkatkan minat konsumen terhadap produk-produk yang dipasarkan. Melalui promosi akan dapat mempengaruhi para konsumen dalam menentukan pilihan produk- produk yang akan dibeli atau digunakannya. Secara umum promosi bertujuan untuk dapat mengoptimalkan tingkat penjualan perusahaan (Rami Syah Putridan Indra Safri, 2015).

Instagram banyak digunakan netizen di seluruh dunia khusnya di indonesia sendiri dari tahun ke tahun pengguna instagram di indonesia semakin tinggi. Berdasarkan situs CNN Indonesia.com saat ini lebih dari 500 juta orang memakai instagram setiap bulannya. Dan 300 jutannya menggunakan layanan instagram setiap hari, pengguna instagram terus bertambah lebih dari dua kali lipat selama 2 tahun terakhir. Instagram sendiri memiliki 22 juta pengguna aktif bulanan di indonesia. Lalu ada sebanyak 95 juta foto dan video yang di publikasikan dengan 4,2 miliar likes per harinya. Perluasan layanan instagram ke ranah global dalam waktu cepat dinilai telah mengalahkan jejaring sosial Twitter dan Facebook. Sejak itu aplikasi media sosial instagram menjadi paling populer. (http://m.cnnidonesia.com/ada-22-juta-pengguna-aktif-instagramindonesia).

Selain menjadi salah satu media sosial yang saat ini menempati posisi puncak teratas. Instagram disebut - sebut menjadi salah satu tempat strategis para pembisnis, dalam hal ini penjual barang online atau pemilik online shop untuk memasarkan barang dagangannya. Dengan instagram tentunya semakin mudah menjual barang karena dapat menunjukan foto barang dagangannya dengan ringkas karena tampilan instagram menjadikan foto produk yang diunggahnya layaknya catalog barang. Secara tidak langsung proses promosi menggunakan instagram tersebut masuk dalam lingkup strategi penjualan online.

Saat ini cukup banyak lembaga atau agen pemasaran yang beralih menggunakan instagram sebagai media promosi pengguna aktif instagram, saat ini mencapai 90 juta pengguna dari banyak nya antusias pengguna instagram tersebut. Banyak nya pembisnis menggunakan media instagram 
sebagi media promosinya. Dapat disaksikan sebanyak 54 persen dari brand ternama telah mengadopsi instagram sebagai bagian dari strategi pemasaran.

\section{METODE PENELITIAN}

Metode penelitian pada dasarnya merupakan cara ilmiah untuk mendapatkan data dengan tujuan dan kegunaan tertentu. Untuk mencapai tujuan yang diperlukan dibutuhkan metode yang relevan untuk mencapai tujuan yang diinginkan (Sugiyono, 2016:1). Penelitian ini dilakukan pada Akun Instagram Merk Kosmetik Lokal di Indonesia. Penelitian ini menggunakan metode eksploratif kuantitatif untuk mengetahui kredibilitas dari performa akun Instagram Merk Kosmetik Lokal Terbaik.. Metode eksploratif merupakan penelitian yang memiliki tujuan untuk melakukan eksplorasi atau memperdalam pengetahuan ataupun ide-ide baru mengenai suatu hal yang baru, guna merumuskan permasalahan secara terperinci (Maryam, Isrok'atun, and Aeni 2016) .

Tujuan dari penelitian ini yaitu mengetahui nilai kredibillitas dari performa akun Instagram Merk Kosmetik Lokal Terbaik yang saya dapatkan dari sumber https://www.tokopedia.com/blog/topbrand-kosmetik-lokal-terbaik/.Peneliti mengambil 10 sample sebagai bahan penelitian. 10 sample tersebut merupakan 10 postingan teratas dari akun yang diteliti.

Langkah-langkah yang dilakukan pada penelitian ini, diantaranya yaitu :

- Melakukan Eksplorasi Pada Website Untuk Menentukan Objek yang Akan Dianalisa.

Eksplorasi ini dilakukan pada beberapa halaman website yang menyediakan informasi mengenai objek yang akan di teliti,sehingga ditemukan nama-nama Brand Kosmetik di Indonesia yang akan dijadikan objek analisa. Setelah melakukan eksplorasi pada halaman website, maka langkah berikutnya yaitu mencari nama akun Instagram dari masing-masing Brand Kosmetik dan memastikan semua memiliki akun Instagram.

- Menghitung Nilai Rata-Rata Variable Dari Merk Kosmetik Lokal Terbaik di Indonesia.

Pada langkah ini, peneliti menghitung nilai variable video views to followers Instagram. Variabel merupakan sesuatu yang memiliki nilai bervariasi dimana nilai tersebut dapat dijadikan sebagai dasar untuk empat data yang berbeda seperti rasio, skala, ordinal, nominal dan internal (Rankuti 2015). Untuk menghitung nilai rata-rata dari variabel video views to followers yaitu dengan cara mengambil 10 postingan kemudian di hitung sehingga menemukan nilai rata-rata dari masing-masing variabel. 


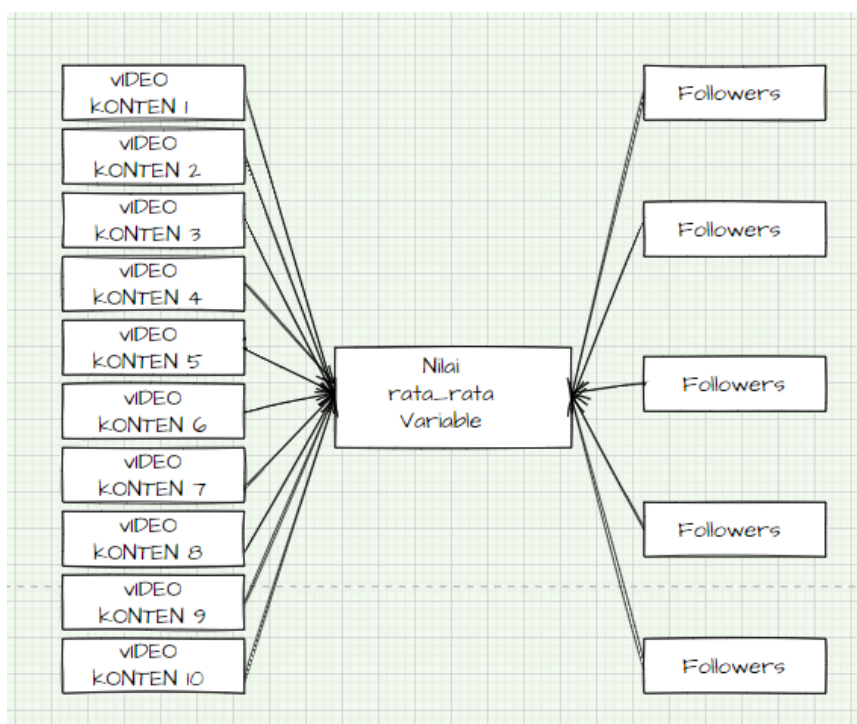

Gambar 1. Analisa Nilai Rata-rata Variabel

- Menghitung Nilai Kredibilitas Rasio untuk menghitung nilai kredibilitas dari video views to followers ratio.

peneliti menggunakan cara membagi nilai variabel pertama dengan nilai variabel kedua. Jika video views memiliki nilai 100 dan followers memiliki nilai 200, maka cara menghitungnya yaitu $100: 200=0,2$. Dengan begitu nilai dari video views to followers ratio adalah 0,2 .

- Menentukan Peringkat Pada Akun Instagram

Langkah terakhir yang dilakukan pada penelitian ini yaitu menentukan peringkat pada masing-masing rasio yang ada. Pada penentuan peringkat perlu melihat karakteristik dari rasio yang di teliti. Jika karakteristik rasio merupakan rendah, maka objek yang memiliki nilai terendah akan mendapatkan angka 5 dan objek yang memiliki nilai tertinggi akan mendapatkan angka 1. Namun jika rasio memiliki karakteritik tinggi maka objek yang mendapatkan nilai tinggi akan mendapatkan angka 5 dan objek yang mendapatkan nilai terendah akan mendapatkan angka 1. Setelah mendapatkan hasil kredibilitas ratio maka dapat disimpulkan objek yang mana mendapatkan peringkat 1 sampai dengan peringkat 5 . 


\section{HASIL DAN PEMBAHASAN}

Akun Instagram dari 5 Merk Kosmetik Lokal Terbaik,yaitu :

\section{a. Emina Kosmetik}

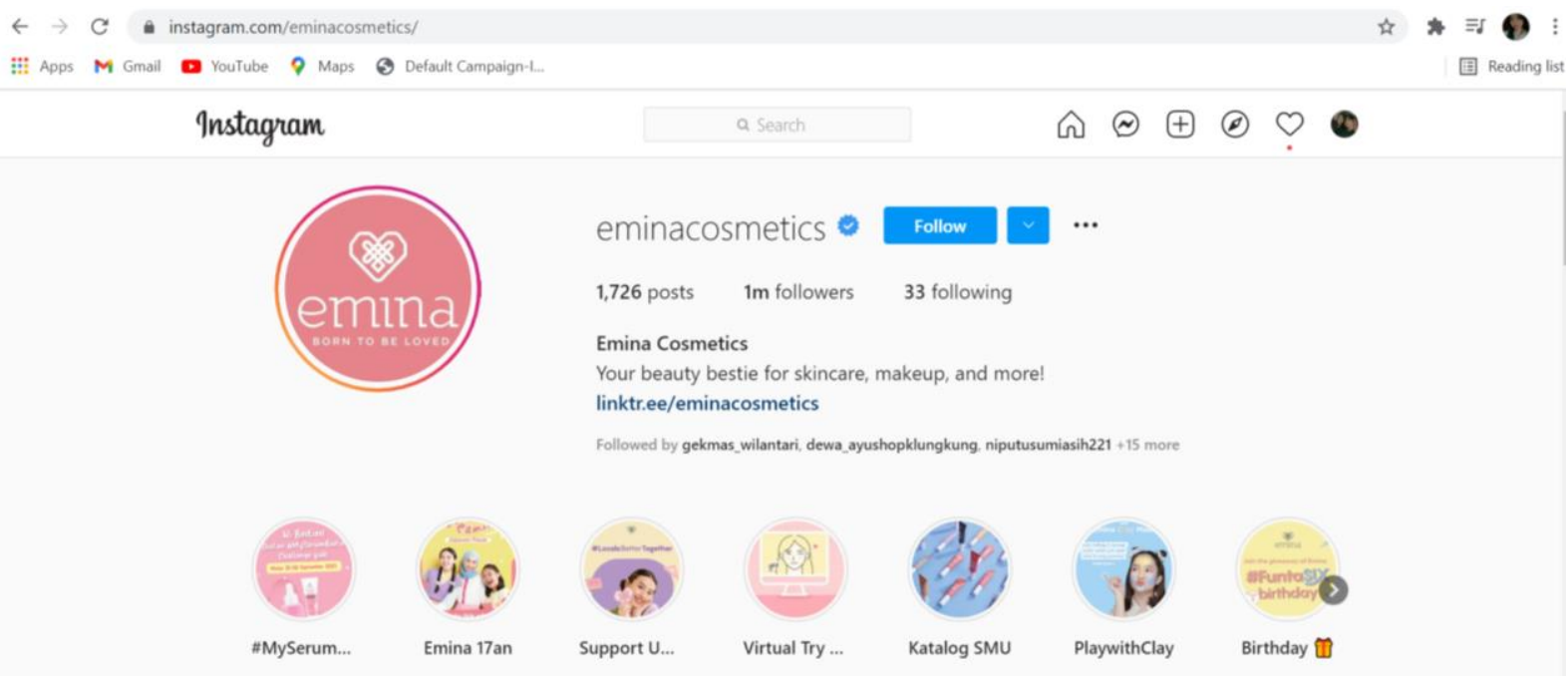

Gambar 2. Akun Instagram Emina Cosmetics

Sumber : https://www.instagram.com/eminacosmetics/

\section{b. Wardah Beauty}

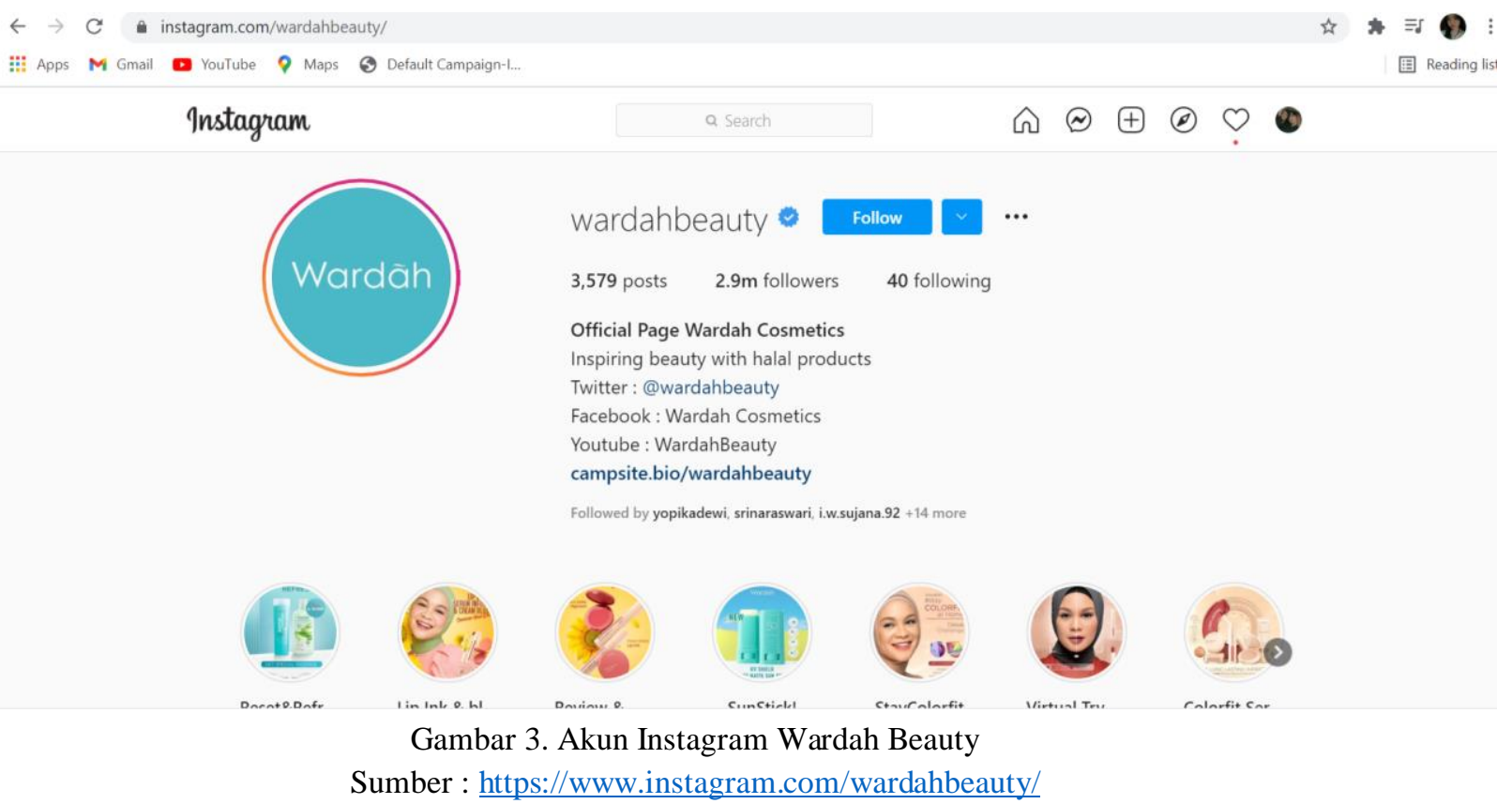




\section{c. Make Over}

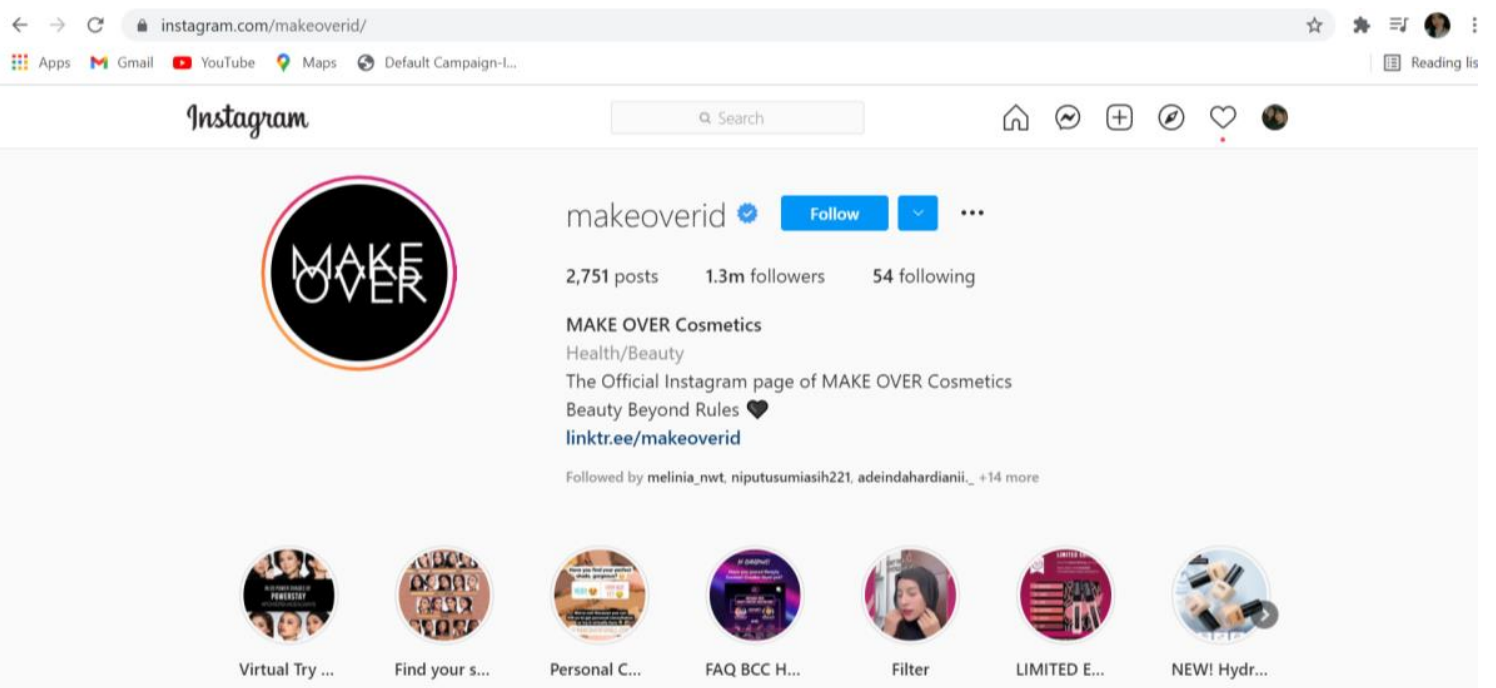

Gambar 4. Akun Instagram Make Over

Sumber : https://www.instagram.com/makeoverid/

\section{d. BLP Beauty}

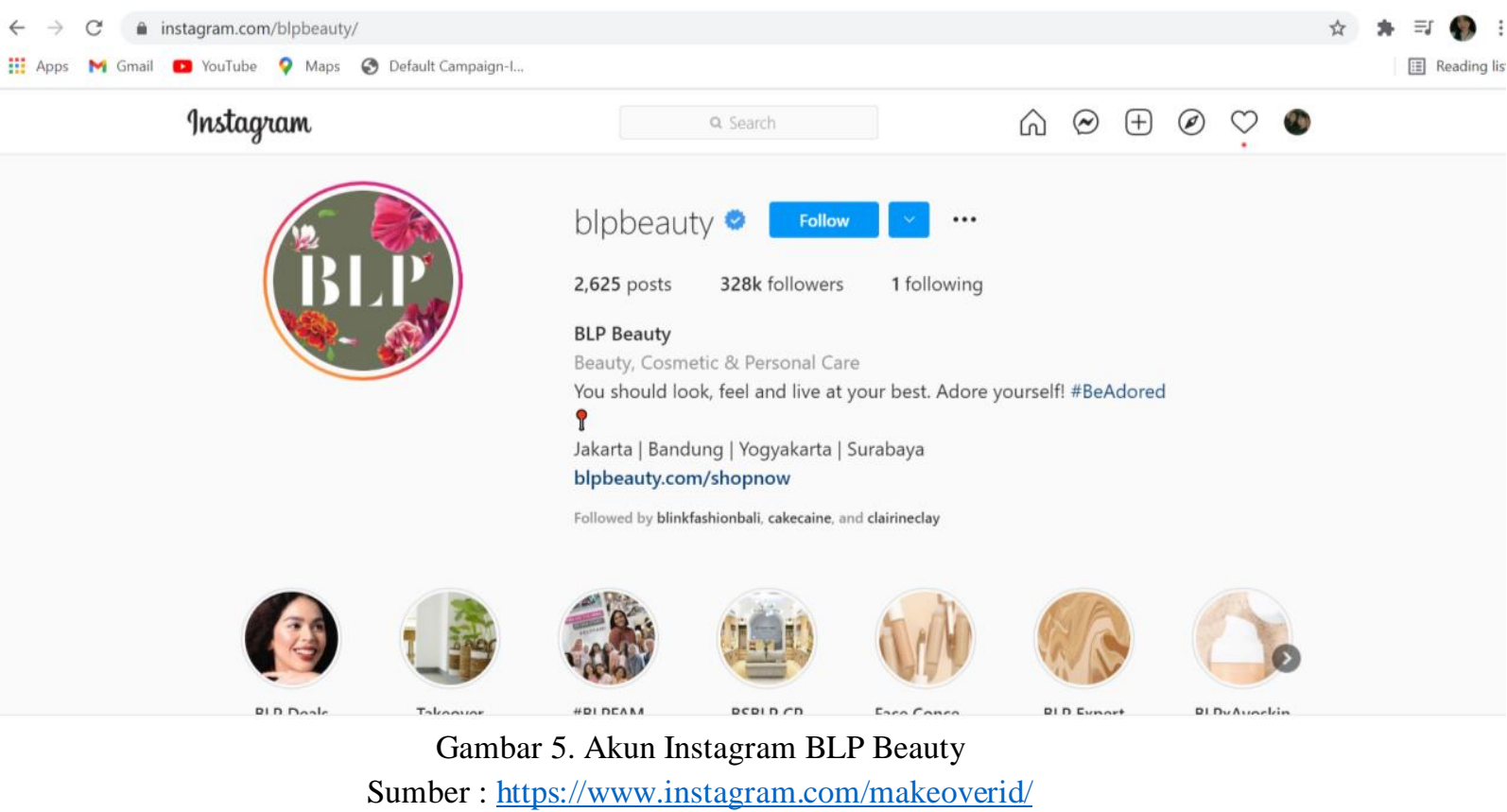




\section{e. Eqsa Cosmetics}

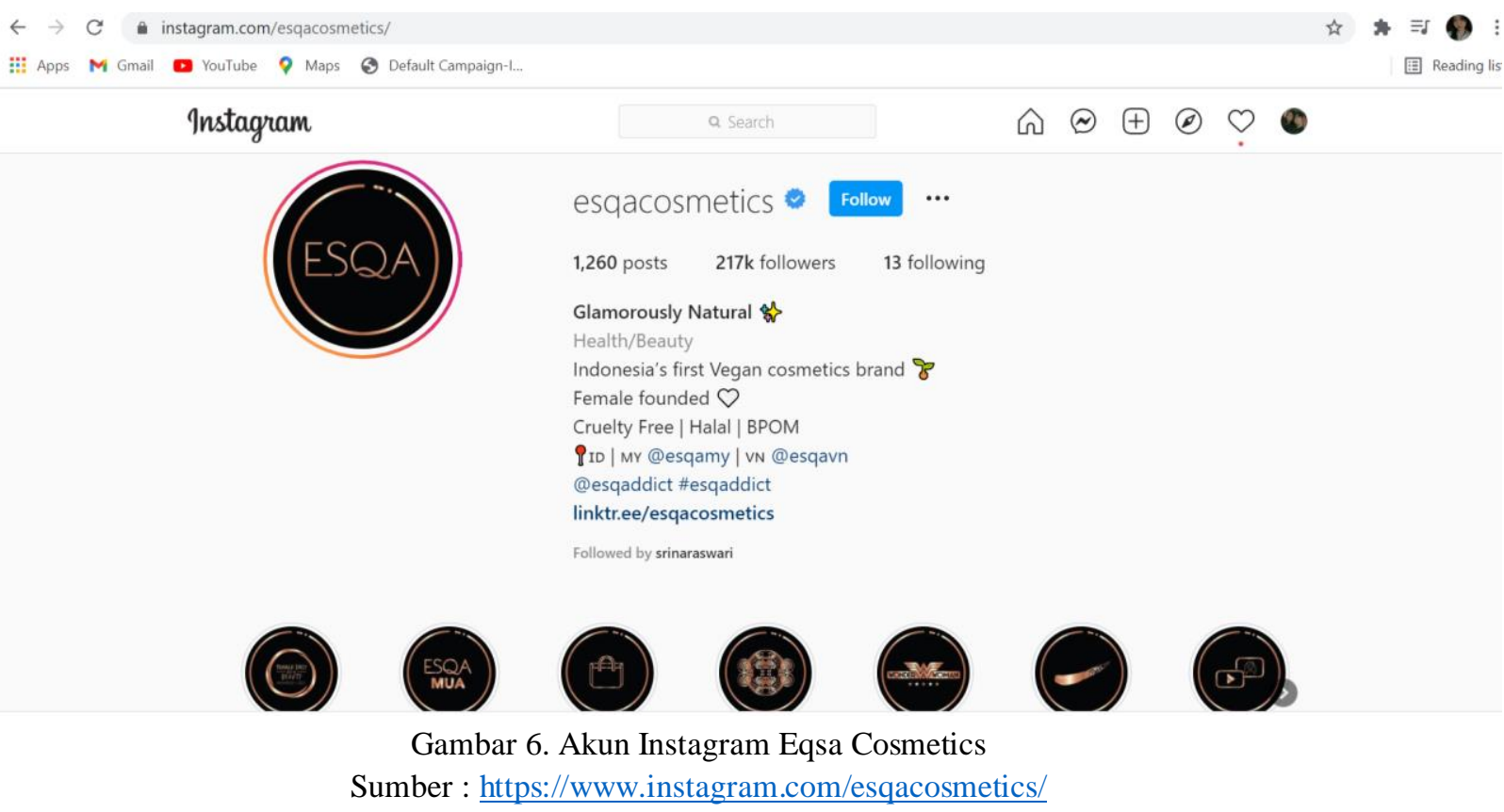

Dari kelima akun Tiktok 5 Tiktokers terbanyak followersnya di Indonesia, peneliti menemukan nilai dari masing-masing variabel yang ada untuk menghitung rasio following to followers dari setiap akun. Pada akun TikTok terdapat 7 variabel, diantaranya yaitu :

1. Likes

2. Followers

3. Following

4. Video Likes

5. Video Comments

6. Video Share

7. Video Views

Dari ketujuh variabel tersebut peneliti hanya focus untuk menemukan hasil dari 2 variabel, yaitu :

1. Video Views

2. Followers

Dari kedua variabel tersebut kemudian dianalisa sehingga menemukan nilai rata-rata dari variabel video views dan variabel followers. Untuk menghitung nilai rata-rata dari variabel video views dan variabel followers yaitu dengan cara mengambil 10 postingan video views dan followersnya kemudian di hitung sehingga menemukan nilai rata-rata dari masing-masing variabel. Berikut merupakan tabel nilai rata-rata dari masing-masing akun Instagram merk kosmetik local terbaik, yaitu : 
Tabel 1. Analisa Nilai Rata-rata Variabel following dan followers akun Instagram Emina Cosmetics

\begin{tabular}{|l|l|l|}
\hline No & Video Views & Followers \\
\hline 1 & 7,518 & 1.000 .000 \\
\hline 2 & 9,770 & \\
\hline 3 & 15,091 & \\
\hline 4 & 11,279 & \\
\hline 5 & 15,857 & \\
\hline 6 & 31,721 & \\
\hline 7 & 20,115 & \\
\hline 8 & 13,677 & \\
\hline 9 & 25,952 & \\
\hline 10 & 10,806 & \\
\hline $\begin{array}{l}\text { Rata- } \\
\text { rata }\end{array}$ & $\mathbf{1 6 , 1 7 9}$ & $\mathbf{1 , 0 0 0 , 0 0 0}$ \\
\hline \multicolumn{3}{|c|}{ Sumber : Pengolah Data Excel }
\end{tabular}

Tabel 2. Analisa Nilai Rata-rata Variabel following dan followers akun Instagram Wardah Beauty

\begin{tabular}{|l|l|l|}
\hline No & Video Views & Followers \\
\hline 1 & 14,237 & $2,900,000$ \\
\hline 2 & 15,814 & \\
\hline 3 & 15,673 & \\
\hline 4 & 12,336 & \\
\hline 5 & 9,192 & \\
\hline 6 & 71,346 & \\
\hline 7 & 123,000 & \\
\hline 8 & 21,375 & \\
\hline 9 & 154,000 & \\
\hline 10 & 16,683 & \\
\hline $\begin{array}{l}\text { Rata- } \\
\text { rata }\end{array}$ & $\mathbf{4 5 , 3 6 6}$ & $\mathbf{2 , 9 0 0 , 0 0 0}$ \\
\hline
\end{tabular}

Sumber : Pengolahan Data Excel 
Tabel 3. Analisa Nilai Rata-rata Variabel following dan followers akun Instagram Make Over

\begin{tabular}{|l|l|l|}
\hline No & $\begin{array}{l}\text { Video } \\
\text { Views }\end{array}$ & Followers \\
\hline 1 & 1,608 & $1,300,000$ \\
\hline 2 & 4,402 & \\
\hline 3 & 27,700 & \\
\hline 4 & 38,000 & \\
\hline 5 & 61,300 & \\
\hline 6 & 12,598 & \\
\hline 7 & 10,341 & \\
\hline 8 & 12,222 & \\
\hline 9 & 146,000 & \\
\hline 10 & 38,916 & \\
\hline $\begin{array}{l}\text { Rata- } \\
\text { rata }\end{array}$ & $\mathbf{3 5 , 3 0 9}$ & $\mathbf{1 , 3 0 0 , 0 0 0}$ \\
\hline \multicolumn{3}{|l|}{ Sumber : Pengolahan Data Excel }
\end{tabular}

Tabel 4. Analisa Nilai Rata-rata Variabel following dan followers akun Instagram BLP Beauty

\begin{tabular}{|l|l|l|}
\hline No & $\begin{array}{l}\text { Video } \\
\text { Views }\end{array}$ & Followers \\
\hline 1 & 1,226 & 328,000 \\
\hline 2 & 932 & \\
\hline 3 & 6,826 & \\
\hline 4 & 11,800 & \\
\hline 5 & 12,400 & \\
\hline 6 & 8,642 & \\
\hline 7 & 10,900 & \\
\hline 8 & 6,524 & \\
\hline 9 & 5,141 & \\
\hline 10 & 22,400 & \\
\hline $\begin{array}{l}\text { Rata- } \\
\text { rata }\end{array}$ & $\mathbf{8 , 6 7 9}$ & $\mathbf{3 2 8 , 0 0 0}$ \\
\hline
\end{tabular}

Sumber : Pengolahan Data Excel 
Tabel 5. Analisa Nilai Rata-rata Variabel following dan followers akun Instagram Eqsa Cosmetics

\begin{tabular}{|l|l|l|}
\hline No & $\begin{array}{l}\text { Video } \\
\text { Views }\end{array}$ & Followers \\
\hline 1 & 11,800 & 216,000 \\
\hline 2 & 1,156 & \\
\hline 3 & 2,388 & \\
\hline 4 & 127,000 & \\
\hline 5 & 3,573 & \\
\hline 6 & 19,752 & \\
\hline 7 & 6,129 & \\
\hline 8 & 7,241 & \\
\hline 9 & 11,100 & \\
\hline 10 & 46,074 & \\
\hline $\begin{array}{l}\text { Rata- } \\
\text { rata }\end{array}$ & $\mathbf{2 3 , 6 2 1}$ & $\mathbf{2 1 6 , 0 0 0}$ \\
\hline
\end{tabular}

Sumber : Pengolahan Data Excel

Setelah menghitung nilai rata-rata tersebut,maka akan menemukan hasil akhir nilai ratarata dari variable video views dan followers Instagram.

Tabel 6. Nilai variable pada akun Instagram 5 Merk Kosmetik Lokal Terbaik

\begin{tabular}{|l|l|l|l|l|l|}
\hline Variabel & $\begin{array}{l}\text { Emina } \\
\text { Cosmetics }\end{array}$ & $\begin{array}{l}\text { Wardah } \\
\text { Beauty }\end{array}$ & Make Over & BLP Beauty & $\begin{array}{l}\text { Eqsa } \\
\text { cosmetics }\end{array}$ \\
\hline $\begin{array}{l}\text { Video } \\
\text { Views }\end{array}$ & 16,179 & 45,366 & 35,309 & 8,679 & 23,621 \\
\hline Followers & $1,000,000$ & $2,900,000$ & $1,300,000$ & 328,000 & 216,000 \\
\hline
\end{tabular}

Pada akun Instagram terdapat 17 rasio yang relevan digunakan untuk mengukur kredibilitas pada masing-masing akun. Namun pada penelitian kali ini hanya berfokus untuk menghitung Video Views to Followers Ratio. Untuk menghitung kredibilitas dari masing-masing akun Instagram setiap Merk, peneliti menghitung dengan cara : variabel 1 akan dibagi dengan variabel 2, sehingga ditemukan hasil analisisa dari rasio tersebut. 
Tabel 7. Hasil perhitungan ratio akun instagram

\begin{tabular}{|l|l|l|l|l|l|l|}
\hline No & Rasio & Emina & $\begin{array}{l}\text { Wardah } \\
\text { Beauty }\end{array}$ & $\begin{array}{l}\text { Make } \\
\text { Over }\end{array}$ & $\begin{array}{l}\text { BLP } \\
\text { Beauty }\end{array}$ & $\begin{array}{l}\text { Eqsa } \\
\text { Cosmetics }\end{array}$ \\
\hline 1 & $\begin{array}{l}\text { Video Views to } \\
\text { Followers Ratio }\end{array}$ & 0 & $\begin{array}{l}0.01564344 \\
8\end{array}$ & 0.0271608 & $\begin{array}{l}0.02646036 \\
6\end{array}$ & $\begin{array}{l}0.10935648 \\
1\end{array}$ \\
\hline
\end{tabular}

Video Views to Followers Ratio memiliki karakteristik yang tinggi sehingga dapat dikatakan bahwa semakin tinggi angka/nilai yang dihasilkan maka semakin baik performa dari akun tersebut. Untuk memberikan peringkat pada masing-masing akun, peneliti memberikan angka 5 pada akun yang mendapatkan nilai tertinggi dan angka satu untuk akun yang mendapatkan nilai terendah. Berikut merupakan table urutan nilai yang dihasilkan oleh masing-masing akun.

Tabel 8. Nilai ratio Instagram 5 Merk kosmetik local terbaik

\begin{tabular}{|l|l|l|l|l|l|}
\hline Karakteristik & Emina Cosmetics & $\begin{array}{l}\text { Wardah } \\
\text { Beauty }\end{array}$ & Make Over & $\begin{array}{l}\text { BLP } \\
\text { Beauty }\end{array}$ & $\begin{array}{l}\text { Eqsa } \\
\text { Cosmetics }\end{array}$ \\
\hline Tinggi & 5 & 4 & 2 & 3 & 1 \\
\hline
\end{tabular}

Sumber : Pengolah Data Excel

Dari tabel nilai ratio akun Instagram 5 Merk kosmetik local terbaik dapat disimpulkan bahwa akun Instagram Emina Cosmetics mendapat nilai tertinggi untuk ratio Video Views to Followers Instagram. Sedangkan akun Instagram Eqsa Cosmetics mendapatkan nilai terendah untuk ratio ini. Jadi, pada penelitian ini Emina Cosmetics memiliki kredibilitas performa yang lebih baik dibandingkan dengan akun Instagram yang lainnya.

\section{KESIMPULAN}

Tujuan dari penelitian ini adalah mengetahui krebilitas performa dari akun Instagram 5 Mer Kosmetik Lokal Terbaik di Indonesia menggunakan Video Views to Followers Ratio. 5 Mer Kosmetik Lokal Terbaik itu adalah Emina Cosmetics,Wardah Beauty,Make Over,BLP Beauty dan Eqsa Cosmetics. Dari Kelima Akun tersebut dapat disimpulkan bahwa :

1. Peringkat pertama adalah Emina Cosmetics dengan nilai tertinggi.

2. Peringkat kedua adalah Wardah Beauty.

3. Peringkat ketiga diraih oleh BLP Beauty.

4. Peringkat keempat adalah Make Over.

5. Peringkat terakhir yaitu peringkat lima adalah Eqsa Cosmetics. 


\section{DAFTAR PUSTAKA}

Hager, G., \& Wellein, G. (2021). Pppp. Introduction to High Performance Computing for Scientists and Engineers, 194-210. https://doi.org/10.1201/ebk1439811924-14

Haryanti, S., Mursito, B., \& Sudarwati. (2017). Analisis Strategi Pemasaran Digital untuk Meningkatkan Penjualan Produk Batik pada PT. Danar Hadi Surakarta. Journal of Chemical Information and Modeling, 53(9), 144-151.

Prihatiningsih, W. (2017). Motif Penggunaan Media Sosial Instagram Di Kalangan Remaja. Communication, 8(1), 51. https://doi.org/10.36080/comm.v8i1.651

Rami Syah Putridan Indra Safri. (2015). 1283-Article Text-3027-1-10-20180308. Pengaruh Promosi Penjualan Dalam Meningkatkan Penjualan Mobil Mitsubishi Pada Pt. Pekan Perkasa Berlian Motor Pekanbaru, 1(2502-1419), 1-25. 